\title{
Association of adipokines, leptin/adiponectin ratio and C-reactive protein with obesity and type 2 diabetes mellitus
}

\author{
Zaid Al-Hamodi, Molham AL-Habori", Ali Al-Meeri and Riyadh Saif-Ali
}

\begin{abstract}
Objective: Alterations in plasma adipokines and/or inflammatory parameters in Type 2 DM remain vague as to whether they are due to obesity and/or directly associated with the diabetic state. Our objective was to compare plasma adiponectin, leptin, leptin/adiponectin ratio (LAR) and hs-CRP in obese non-diabetic subjects and non-obese Type 2 DM patients, as well as determining the association of these adipokines with MetS and diabetes-related quantitative traits.

Methods: In this study, 92 Yemeni male volunteers aged 25-60 years old were enrolled, 31 of whom were healthy subjects with $\mathrm{BMI}<25 \mathrm{~kg} / \mathrm{m}^{2}$ served as control; 30 non-diabetic obese subjects $\mathrm{BMl} \geq 30 \mathrm{~kg} / \mathrm{m}^{2}$ and $\mathrm{FBG}<6.1 \mathrm{mmol} / \mathrm{l}$; and 31 non-obese Type 2 DM with FBG $>7 \mathrm{mmol} / \mathrm{l}$ and $\mathrm{BMl}<25 \mathrm{~kg} / \mathrm{m}^{2}$.

Results: Adiponectin was lower in obese subjects, with no differences between non-obese Type 2 DM patients and controls. In contrast, leptin, LAR and hs-CRP were higher in both obese subjects and non-obese Type 2 DM patients. Linear regression analysis showed adiponectin to be associated negatively with BMl, waist circumference, insulin, HOMA- $\beta$ and HOMA-IR; whereas leptin, LAR and hs-CRP were associated positively with BMl, waist circumference, TG, FBG, insulin, HOMA- $\beta$ and HOMA-IR. Moreover, adiponectin negatively correlated with leptin, LAR and hs-CRP; whereas leptin and LAR positively correlated with hs-CRP and with each other.
\end{abstract}

Conclusion: Plasma adiponectin is not affected by diabetes per se, suggesting that its alterations in Type 2 DM may be due to obesity and may be an important link between adiposity, IR and Type 2 DM.

Keywords: Type 2 DM, Obesity, Adiponectin, Leptin, Leptin/Adiponectin ratio, hs-CRP

\section{Introduction}

Type $2 \mathrm{DM}$ is a heterogeneous disorder characterized by two interrelated metabolic defects: insulin resistance (IR) coupled with impaired $\beta$-cell function $[1,2]$. In individuals with impaired glucose tolerance (IGT), numerous genetic, host-related, and environmental factors contribute to the progression of IR to Type 2 DM. Obesity, and especially visceral adipose tissue accumulation, increases the risk of developing Type 2 DM [3]. The greater risk of Type $2 \mathrm{DM}$ in the obese can partly be explained by changes in adipose tissue function $[4,5]$. In the last

\footnotetext{
*Correspondence: malhabori@hotmail.com

Department of Biochemistry and Molecular Biology, Faculty of Medicine and Health Sciences, University of Sana'a, PO Box 19065, Sana'a, Republic of
} Yemen

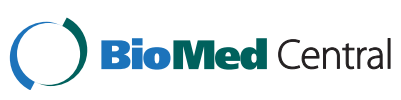

(c) 2014 Al-Hamodi et al.; licensee BioMed Central Ltd. This is an Open Access article distributed under the terms of the Creative Commons Attribution License (http://creativecommons.org/licenses/by/4.0), which permits unrestricted use, distribution, and reproduction in any medium, provided the original work is properly credited. The Creative Commons Public Domain Dedication waiver (http://creativecommons.org/publicdomain/zero/1.0/) applies to the data made available in this article, unless otherwise stated. decade, a hypothesis was proposed to associate the pathogenesis of Type 2 DM with a state of subclinical chronic inflammation [6,7]. Epidemiological studies have demonstrated an increase in plasma levels of inflammatory markers such as C-reactive protein (CRP), interleukin-6 (IL-6) and tumour necrosis factor- $\alpha$ (TNF- $\alpha$ ) in patients with metabolic syndrome (MetS) and also in those with clinically overt Type 2 DM [8]. Chronically elevated levels of these biomarkers promote IR in skeletal muscle and endothelial dysfunction [9] as well as in adipose and other tissues, thereby increasing the risk for Type 2 DM [10].

Adiponectin is almost exclusively secreted by adipocytes and appears to acts as a hormone with antiinflammatory and insulin-sensitizing properties in vitro and in animal models and may also promote $\beta$-cell 
function and survival [11,12]. Adiponectin is almost unique among adipokines because its systemic levels decrease in obesity, whereas most other adipokines (in particular the pro-inflammatory adipokines) are released in larger amounts with cell size [12,13]. Adiponectin levels are decreased in cardiovascular disease and several metabolic disorders including obesity, inflammatory states, IR, and Type 2 DM $[14,15]$. Several clinical studies have demonstrated hypoadiponectinemia correlates with the development of IR and Type 2 DM [16-19]. The majority of these studies show the adiponectin level in Type 2 DM to be often reduced, even in the relative early stage of this condition, such as at time of diagnosis [20,21]. A range of prospective studies demonstrated that high levels of circulating adiponectin are associated with low risk of Type 2 DM even after adjustment for multiple factors that could confound this relationship [22-25].

Leptin is a peptide hormone mainly secreted by white adipose tissue [26]. Its expression and release are increased in large adipocytes even after normalization for fat cell volume so that its regulation shows similarities to the regulation of pro-inflammatory immune-mediators in adipocytes [13]. It acts on the hypothalamus, leading to decreased appetite and increased energy expenditure, thereby regulating body weight [27]. Furthermore, leptin has a number of other activities, including regulation of endocrine function, reproduction and immunity $[26,28]$. In humans, obesity is associated with high circulating leptin levels probably reflecting a state of leptin resistance, i.e. impaired leptin signalling and action. This state could interfere with the physiological relationship between leptin and $\beta$-cell function and promote the development of IR and Type 2 DM [29]. Previous epidemiological studies investigating the association between circulating leptin levels and incident of Type 2 DM yielded discrepant results $[16,30]$.

It remains unclear whether the observed alterations in plasma adipokines and/or inflammatory parameters in Type 2 DM are due to excess adipose tissue mass and/or directly associated with the diabetic state [31,32]. We hypothesize that altered plasma adipokine and/or inflammatory factor levels are related to the obese state and are not prevalent in non-obese Type 2 DM. The present study compares plasma adipokines and inflammatory markers between obese non-diabetic individuals and non-obese Type 2 DM patients versus non-obese, normoglycemic controls; as well as evaluating the association of adipokines and inflammatory markers with metabolic syndrome and diabetes-related quantitative traits. We also examined the Leptin/Adiponectin ratio (LAR) in view of previous reports suggesting that LAR being a better indicator of IR than the single adipokines [33].

\section{Research design and methods}

\section{Study subjects}

For this study, a total of 92 Yemeni men subjects aged 25-60 years were recruited from Al-Thwara Hospital, Sana'a. Thirty one were healthy non-obese, normoglycaemic subjects with a $\mathrm{BMI}<25 \mathrm{~kg} / \mathrm{m}^{2}$ served as controls; 30 obese non-diabetic subjects with $\mathrm{BMI} \geq 30 \mathrm{~kg} / \mathrm{m}^{2}$ and FBG $<6.1 \mathrm{mmol} / \mathrm{L}$; and 31 non-obese Type 2 DM patients with blood glucose $>7 \mathrm{mmol} / \mathrm{l}$ and $\mathrm{BMI}<25 \mathrm{~kg} / \mathrm{m}^{2}$. Obese Type 2 DM patients were excluded in order to examine the role of diabetes per se. In general, subjects with acute or chronic infections, severe medical conditions (malignancy, renal failure, liver cirrhosis, connective tissue disease, and chronic congestive heart failure) were excluded from the study. The study protocol was approved by the institutional review board (IRB) of the Faculty of Medicine and Health Sciences, Sana'a University. Informed consent was obtained from all individuals after explaining the purpose and nature of the study.

Blood pressure (BP) measurements were taken from each patient's right arm in the seated position by using an Omron IntelliSense Automatic Blood Pressure Monitor after $10 \mathrm{~min}$ of rest in a quiet room. Two to three successive BP readings were obtained at 5 minutes intervals and averaged. Body weight and height were measured without shoes in the morning, and BMI was computed as weight in kilograms $(\mathrm{kg})$ divided by height in meters squared $\left(\mathrm{m}^{2}\right)$. Waist circumference was measured midway between the lower rib margin and the superior iliac spine at the end of gentle expiration in a standing position. Fasting venous blood $(6 \mathrm{ml})$ was collected from each subject after 12 hours fast and immediately taken into 2 labelled test tubes, sodium fluoride (for glucose measurement) and plain tubes for other biochemical investigations. The plain tubes were centrifuged for 15 minutes at 2500-3000 $\times$ g within 30 minutes of blood collection and the serum from each sample was separated into four micro tubes and immediately kept at $-20^{\circ} \mathrm{C}$ until analysis. Plasma glucose was determined immediately after centrifugation.

\section{Biochemical analyses}

Serum triglyceride (TG), HDL-cholesterol (HDL-c), and plasma glucose (FPG) were manually measured by their respective kits (Human Company, Germany). Insulin was measured by Electrochemiluminescence immunoassay (ECL) on Elecsys autoanalyzer (Roche Diagnostics, Germany). Insulin resistance and Insulin sensitivity (IS) were calculated using the Homeostasis Model Assessment (HOMA 2) Calculator v2.2 which is available from Oxford Centre for Diabetes, Endocrinology and Metabolism. ELISA kits were used to measure serum adiponectin (R\&D Systems, USA), serum leptin and hs-CRP (DRG Diagnostics, Germany). 


\section{Statistical analyses}

The results were analyzed by the Social Package of Statistical Science (SPSS) software version 11.5 (SPSS Inc., Chicago, IL, USA). Age, BMI, waist circumference, systolic blood pressure (SBP), diastolic blood pressure (DBP), TG, HDL-c, FBG, insulin, IS, HOMA-IR, adiponectin, leptin, LAR and hs-CRP were log transformed because they were not normally distributed. These parameters means and 95\% confidence intervals were transformed back and reported as geometric means. ANOVA test was used to describe the mean differences among groups of study. General linear model, univariate analyses (ANCOVA) adjusted for age was used to assess the differences of adiponectin, leptin, LAR and hs-CRP between obese non-diabetic, non-obese Type 2 DM and normal subjects. The association of adiponectin, leptin, LAR and hs-CRP with metabolic syndrome and diabetesrelated qualitative traits: BMI, waist circumference, SBP, DBP, TG, HDL-c, FBG, insulin, IS, HOMA- $\beta$ and HOMA-IR (dependent variables) were analyzed by hierarchical linear regression adjusted for age in a combined group: normal and obese non-diabetic subjects. The interrelationship between adiponectin, leptin, LAR and hs-CRP in non-diabetic subjects were evaluated by linear regression controlled for age.

\section{Results}

The demographic and biochemical parameters of the subjects are shown in Table 1 . The adiponectin, leptin, LAR and hs-CRP assessed by general linear model (univariate) are shown in Table 2. Serum levels of adiponectin were significantly lower in obese non-diabetic subjects compared to control and non-obese Type $2 \mathrm{DM}$ subjects ( $p=0.002,0.006$ respectively), with no differences in adiponectin levels between non-obese Type 2 DM subjects and controls. In contrast, serum leptin levels and LAR were higher in both obese non-diabeic subjects $\left(\mathrm{p}=3.6 \times 10^{-30}, 1.1 \times 10^{-26}\right)$ and non-obese Type $2 \mathrm{DM}\left(\mathrm{p}=2.8 \times 10^{-19}, 2.9 \times 10^{-12}\right.$, respectively) as compared to control subjects. In addition, serum leptin levels and LAR in obese subjects were higher with respect to non-obese Type $2 \mathrm{DM}$ subjects $\left(\mathrm{p}=2.7 \times 10^{-4}, 1.4 \times 10^{-7}\right.$, respectively). Similarly, serum hs-CRP levels were higher in both obese subjects and non-obese Type $2 \mathrm{DM}$ patients as compared to control subjects $\left(\mathrm{p}=4.3 \times 10^{-6}\right.$, $8.2 \times 10^{-10}$, respectively). Unlike that of leptin and LAR, serum hs-CRP levels were higher in non-obese Type 2 DM than those in obese subjects $(\mathrm{p}=0.019)$.

The association of the inflammatory related variables (adiponectin, leptin, LAR and hs-CRP) with metabolic syndrome and diabetes-related qualitative traits was evaluated in the combined group; normal and obese nondiabetic subjects (Table 3). Serum levels of adiponectin associated with increased HDL-c and IS, and decreased
BMI, waist circumference, insulin, HOMA- $\beta$ and HOMAIR. In contrast, serum leptin levels and LAR associated with decreased IS, and increased BMI, waist circumference, DBP, SBP, TG, FBG, insulin, HOMA- $\beta$ and HOMA-IR. On the other hand, hs-CRP associated with decreased HDL-c and IS, and increased BMI, waist circumference, DBP, SBP, TG, FBG, insulin, HOMA- $\beta$, and HOMA-IR.

The interrelationship between adiponectin, leptin, LAR and hs-CRP parameters was further assessed in the combined group; normal and obese non-diabetic subjects as shown in Table 4. Serum adiponectin levels negatively correlated with leptin, LAR and hs-CRP $\left(r^{2}=-0.216\right.$, $\left.\mathrm{p}=0.002 ; \mathrm{r}^{2}=-0.268, \mathrm{p}=0.0001 ; \mathrm{r}^{2}=-0.098, \mathrm{p}=0.006\right)$. In contrast, serum leptin levels and LAR positively correlated with hs-CRP $\left(\mathrm{r}^{2}=-0.528, \mathrm{p}=5.8 \times 10^{-11} ; \mathrm{r}^{2}=-0.527, \mathrm{p}=\right.$ $6.7 \times 10^{-11}$ respectively), and with each other $\left(r^{2}=-0.668\right.$, $\left.\mathrm{p}=1.4 \times 10^{-14}\right)$.

\section{Discussion}

The results presented in our study shows plasma adiponectin not to be affected by diabetes per se whereby adiponectin was significantly lower in obese individuals as compared to both control and non-obese Type 2 DM, with no difference in adiponectin between non-obese Type $2 \mathrm{DM}$ and control group; thus suggesting that the often reported alterations in plasma adiponectins in Type 2 DM [32,34,35] may be due to excess adipose tissue mass/ obesity. In accordance with our results, a recent finding suggested that adiponectin levels in patients with Type 2 DM seem to be more associated with obesity and less with diabetes [36]. In general most of the Type 2 DM patients included in those studies were obese. To differentiate between the impact of obesity and type 2 diabetes on the altered plasma adipokine and/or inflammatory profiles, a recent study compares basal plasma adipokines and inflammatory markers between obese and non-obese type 2 diabetes patients versus non-obese, normoglycemic controls and conclude that the observed alterations in these parameters in obese type 2 diabetes patients as opposed to non-obese Type $2 \mathrm{DM}$ are attributed to the greater adipose tissue mass, and not necessarily to the presence of the type 2 diabetic state [37]. Taking into account the ethnical variation our study was designed to assess the association of these adipokines in Yemeni Type 2 DM patients as well as highlighting the impact of diabetes per se.

Our results also show adiponectin to be associated with metabolic syndrome and diabetes-related qualitative traits, whereby adiponectin was associated with increased HDL-C and IS; and decreased BMI, waist circumference, insulin, HOMA-IR and HOMA- $\beta$; which is in line with previous studies [38-40]. Many studies suggest that adiponectin is an important regulator of insulin sensitivity and glucose homeostasis, with several reports 
Table 1 Demographic and biochemical parameters among normal, non-diabetic obese and non-obese type 2 diabetes mellitus groups

\begin{tabular}{|c|c|c|c|}
\hline Parameters & Normal $(n=31)$ & Non-diabetic obese $(n=30)$ & Non-obese T2DM $(n=31)$ \\
\hline Age (years) & $31.3(27.8-35.2)$ & $28.4(26.6-32.4)$ & $45.2(39.8-51.3)$ \\
\hline p-value & & ${ }^{\mathrm{a}} 0.44$ & ${ }^{\mathrm{a}} 4.5 \times 10^{-5},{ }^{\mathrm{b}} 4.0 \times 10^{-5}$ \\
\hline BMI $\left(\mathrm{kg} / \mathrm{m}^{2}\right)$ & $20.6(19.7-21.5)$ & $34.0(32.5-35.5)$ & $22.3(21.1-23.7)$ \\
\hline p-value & & ${ }^{\mathrm{a}} 5.1 \times 10^{-9}$ & ${ }^{\mathrm{a}} 0.53,{ }^{\mathrm{b}} 5.1 \times 10^{-9}$ \\
\hline Waist circumference $(\mathrm{cm})$ & $75.1(72.7-77.6)$ & $90.2(88.0-92.5)$ & $71.3(69.2-73.5)$ \\
\hline p-value & & ${ }^{\mathrm{a}} 5.1 \times 10^{-9}$ & ${ }^{a} 0.037,{ }^{b} 5.1 \times 10^{-9}$ \\
\hline $\mathrm{DBP}(\mathrm{mmHg})$ & $75.5(72.5-78.7)$ & $85.2(82.8-87.6)$ & $83.5(79.8-87.3)$ \\
\hline$p$-value & & $4.9 \times 10^{-5}$ & ${ }^{\mathrm{a}} 0.00096,{ }^{\mathrm{b}} 0.74$ \\
\hline SBP $(\mathrm{mmHg})$ & $113(109-117)$ & $126(123-130)$ & $123(116-130)$ \\
\hline p-value & & ${ }^{\mathrm{a}} 2.3 \times 10^{-4}$ & ${ }^{\mathrm{a}} \mathbf{0 . 0 0 9},{ }^{\mathrm{b}} 0.56$ \\
\hline Triglyceride (mmol/l) & $1.5(1.2-1.8)$ & $2.1(2.0-2.2)$ & $2.0(1.8-2.2)$ \\
\hline p-value & & ${ }^{\mathrm{a}} 0.0009$ & ${ }^{\mathrm{a}} \mathbf{0} .005,{ }^{\mathrm{b}} 0.88$ \\
\hline HDL-c (mmol/l) & $0.9(0.8-1.0)$ & $0.8(0.7-0.9)$ & $0.7(0.6-0.8)$ \\
\hline p-value & & ${ }^{\mathrm{a}} 0.23$ & ${ }^{\mathrm{a}} \boldsymbol{0 . 0 1},{ }^{\mathrm{b}} 0.34$ \\
\hline FBG (mmol/l) & $5.4(5.1-5.8)$ & $5.7(5.5-6.0)$ & $9.7(8.3-11.4)$ \\
\hline p-value & & ${ }^{\mathrm{a}} 0.66$ & ${ }^{\mathrm{a}} 5.1 \times 10^{-9},{ }^{\mathrm{b}} 5.2 \times 10^{-9}$ \\
\hline Insulin (pmol/l) & $44.5(37.2-53.2)$ & $130(112-151)$ & $70.1(54.3-90.5)$ \\
\hline p-value & & $5.1 \times 10^{-9}$ & ${ }^{\mathrm{a}} 0.004,5.9 \times 10^{-5}$ \\
\hline HOMA- $\beta$ & $73.2(62.3-85.9)$ & 135 (119-154) & $33.7(23.0-49.2)$ \\
\hline p-value & & ${ }^{\mathrm{a}} 0.0007$ & ${ }^{\mathrm{a}} 3.2 \times 10^{-5},{ }^{\mathrm{b}} 5.1 \times 10^{-9}$ \\
\hline Insulin Sensitivity (\%) & 118 (99-142) & $40.8(35.2-47.3)$ & $62.4(49.0-79.3)$ \\
\hline$p$-value & & $5.1 \times 10^{-9}$ & ${ }^{\mathrm{a}} 1.6 \times 10^{-5}, 0.006$ \\
\hline HOMA-IR & $0.9(0.7-1.1)$ & $2.5(2.2-2.9)$ & $1.7(1.3-2.2)$ \\
\hline p-value & & ${ }^{\mathrm{a}} 5.1 \times 10^{-9}$ & $4.9 \times 10^{-5}, 0.005$ \\
\hline
\end{tabular}

Result presented as geometric mean and $95 \%$ confidence interval of mean; ${ }^{\mathrm{a}} \mathrm{vs.}$ normal group; ${ }^{\mathrm{b}} \mathrm{vs.}$ non-diabetic obese group evaluated by ANOVA.

Table 2 Comparison of adiponectin, leptin, leptin/ adiponectin ratio (LAR) and hs-CRP between normal, non-diabetic obese and non-obese type 2 DM groups

\begin{tabular}{|c|c|c|c|}
\hline Parameters & $\begin{array}{l}\text { Normal } \\
(\mathrm{n}=31)\end{array}$ & $\begin{array}{c}\text { Non-diabetic } \\
\text { obese }(n=30)\end{array}$ & $\begin{array}{c}\text { Non-obese } \\
\text { T2DM }(n=31)\end{array}$ \\
\hline Adiponectin (IU/ml) & $25(20.6-30.2)$ & $16.3(13.3-19.9)$ & $25.8(20.6-32.2)$ \\
\hline p-value & & ${ }^{\mathrm{a}} 0.002$ & ${ }^{\mathrm{a}} 0.83,{ }^{\mathrm{b}} \mathbf{0 . 0 0 6}$ \\
\hline Leptin (ng/ml) & $14(12-17)$ & $141(116-172)$ & 78 (63-96) \\
\hline p-value & & $3.6 \times 10^{-30}$ & $\begin{array}{l}{ }^{a} 2.8 \times 10^{-19}, \\
{ }^{b} 2.7 \times 10^{-4}\end{array}$ \\
\hline $\begin{array}{l}\text { Leptin/Adiponectin } \\
\text { Ratio }\end{array}$ & $0.59(0.36-0.85)$ & $8.21(6.78-9.90)$ & $3.31(2.61-4.15)$ \\
\hline$p$-value & & $1.1 \times 10^{-26}$ & $\begin{array}{l}{ }^{a} 2.9 \times 10^{-12} \\
{ }^{b} 1.4 \times 10^{-7}\end{array}$ \\
\hline hs-CRP (U/ml) & $15.2(14.7-15.7)$ & $17.0(16.5-17.7)$ & $18.2(17.6-19.0)$ \\
\hline p-value & & ${ }^{\mathrm{a}} 4.3 \times 10^{-6}$ & $\begin{array}{c}{ }^{\mathrm{a}} 8.2 \times 10^{-10} \\
{ }^{\mathrm{b}} 0.019\end{array}$ \\
\hline
\end{tabular}

Results presented as geometric mean and 95\% confidence interval of mean adjusted for age; ${ }^{a}$ vs. normal group, ${ }^{b}$ vs. non-diabetic obese group evaluated by univariate (General Linear Model). confirming an inverse relationship between insulin resistance and plasma adiponectin levels [19,23,41]. The evidence that insulin may have direct effect on adiponectin gene expression and adiponectin concentrations in vitro [42] may infer that the higher levels of insulin in insulin-resistant subjects may down-regulate levels of adiponectin [43]. However, the inverse association between adiponectin and IR in our results and others $[39,40]$ may possibly be mediated not only by insulin but also by inflammatory cytokines [44]. Moreover, the positive association between adiponectin and HDL-c is in support of earlier studies in the general population [38] and obese subjects [45], suggesting that adiponectin plays a role in HDL metabolism.

Unlike adiponectin, serum leptin levels and LAR were higher in both obese individuals and non-obese Type 2 DM patients with respect to the control group. In addition, serum leptin levels and LAR in obese subjects were higher compared to non-obese Type 2 DM. Our 
Table 3 Association of adiponectin, leptin, leptin/adiponectin ratio (LAR) and hs-CRP with metabolic syndrome and diabetic parameters among non-diabetic subjects $(n=61)$

\begin{tabular}{|c|c|c|c|c|}
\hline Metabolic syndrome parameters & Adiponectin (IU/ml) & Leptin (ng/ml) & Leptin/Adiponectin Ratio & hs-CRP (U/ml) \\
\hline BMI (kg/m2) & $-0.213(0.0007)$ & $0.049\left(1.1 \times 10^{-11}\right)$ & $0.208\left(3.2 \times 10^{-9}\right)$ & $3.256\left(2.2 \times 10^{-10}\right)$ \\
\hline Waist circumference $(\mathrm{cm})$ & $-0.368\left(9.5 \times 10^{-5}\right)$ & $0.070\left(1.6 \times 10^{-9}\right)$ & $0.706\left(8.2 \times 10^{-7}\right)$ & $5.302\left(2.1 \times 10^{-10}\right)$ \\
\hline $\mathrm{DBP}(\mathrm{mmHg})$ & $-0.032(0.789)$ & $0.044(0.001)$ & $0.481(0.003)$ & $2.955(0.002)$ \\
\hline SBP $(\mathrm{mmHg})$ & $0.009(0.916)$ & $0.032(0.001)$ & $0.309(\mathbf{0 . 0 1 )}$ & $1.685(0.015)$ \\
\hline Triglyceride (mmol/l) & $-0.004(0.208)$ & $0.002(0.0001)$ & $0.014(0.003)$ & $0.127\left(2.8 \times 10^{-6}\right)$ \\
\hline HDL-c (mmol/l) & $0.005(0.034)$ & $-0.0003(0.203)$ & $-0.006(0.061)$ & $-0.035(0.050)$ \\
\hline LDL-c (mmol/l) & $-0.011(0.157)$ & $0.003(0.0016)$ & $0.024(0.032)$ & $0.117(0.074)$ \\
\hline FBG (mmol/l) & $-0.005(0.468)$ & $0.003(0.003)$ & $0.023(0.02)$ & $0.143(0.016)$ \\
\hline Insulin (pmol/l) & $-1.163(0.018)$ & $0.285\left(1.1 \times 10^{-6}\right)$ & $0.342\left(5.3 \times 10^{-6}\right)$ & $22.91\left(1.6 \times 10^{-8}\right)$ \\
\hline НОМА- $\beta$ & $-1.152(0.006)$ & $0.132(0.01)$ & $0.143(0.002)$ & $14.44\left(6.3 \times 10^{-5}\right)$ \\
\hline Insulin Sensitivity (\%) & $1.583(0.001)$ & $-0.279\left(2.7 \times 10^{-5}\right)$ & $-0.248(0.0001)$ & $-20.3\left(\left(4.3 \times 10^{-6}\right)\right.$ \\
\hline HOMA-IR & $-0.021(0.021)$ & $0.006\left(6.3 \times 10^{-7}\right)$ & $0.344\left(4.6 \times 10^{-6}\right)$ & $0.436\left(1.3 \times 10^{-8}\right)$ \\
\hline
\end{tabular}

Results presented represent $b$ values ( $p$ values) assessed by linear regression adjusted for age; (b) coefficient for the relationship between the dependent variables (adiponectin, leptin, LAR and hs-CRP) and the independent variables (metabolic syndrome and diabetic parameters).

results are consistent with previous studies showing circulating leptin levels to be higher in obese individuals and patients with MetS [40,46]. Earlier reports showed circulating leptin concentrations to be elevated in obese subjects in proportion to the degree of adiposity [46] and positively correlated with body fat mass, despite anti-obesity actions of leptin [47]. In vitro studies also indicated that leptin secretion was significantly greater in enlarged adipocytes [13].

Our results show that adiponectin levels and that of leptin and LAR exhibit opposing and variable correlations with obesity, IR and the components of the metabolic syndrome; whereby leptin levels and LAR were associated with decreased IS and increased BMI, waist circumference, SBP, DBP, TG, FBG, insulin, HOMA-IR and HOMA- $\beta$. These findings are in agreement with previous studies $[39,40,48]$. High leptin levels generally associated with high insulin levels could be partially explained by a state of leptin resistance such that chronically elevated leptin levels in obesity may result in decreased responsiveness of the receptor system in pancreatic $\beta$ cells, leading to increased insulin secretion. The resulting hyperinsulinaemia in turn could exacerbate obesity and further increase leptin levels, resulting in a positive feedback loop that could promote the development of diabetes [24,29]. Accordingly, our results show a close relationship between insulin and leptin levels in non-diabetic obese subjects.

Our results also show an inverse association between leptin and adiponectin which highlights the recent findings that indicated that the two adipokines interact with each other in the modulation of Type 2 DM risk [24]. Perhaps this association could be secondary to the inverse relation of these adipokines with fat mass; direct relation of leptin; and inverse relation of adiponectin. In obesity where plasma adipokine levels are reduced, this can be used as a marker of insulin resistance and predict the development of Type 2 DM and atherosclerosis [41]. The observed increase in LAR in both obese individuals and non-obese Type $2 \mathrm{DM}$ as compared to the increase in HOMA-IR may suggest that LAR could be a useful index for insulin resistance. This is in line with recent suggestion that LAR could serve as a useful index for insulin resistance in clinical practice and a good indicator for assessing the effectiveness of anti-diabetic therapy [33] as well as a potential atherogenic index in obese Type 2 DM patients [49].

Since chronic inflammation is likely to play a role in the pathogenesis of Type $2 \mathrm{DM}$, we also examined the association between adipocytokines and hs-CRP, an

Table 4 Correlation between adiponectin, leptin, leptin/Adiponectin ratio and hs-CRP parameters among non-diabetic subjects $(n=61)$

\begin{tabular}{lcccc}
\hline Parameters & Adiponectin $(\mathrm{IU} / \mathrm{ml})$ & Leptin $(\mathrm{ng} / \mathrm{ml})$ & Leptin/Adiponectin ratio & hs-CRP $(\mathrm{U} / \mathrm{ml})$ \\
\hline Adiponectin $(\mathrm{IU} / \mathrm{ml})$ & $\mathbf{1}$ & $-0.216(0.002)$ & $-0.268(0.0001)$ & $-0.098(0.006)$ \\
Leptin & & 1 & $0.668\left(1.4 \times 10^{-14}\right)$ & $0.528\left(5.8 \times 10^{-11}\right)$ \\
Leptin/Adiponectin & & & 1 & $0.527\left(6.7 \times 10^{-11}\right)$ \\
\hline
\end{tabular}

Result presented as adjusted $r^{2}$ (P-value) assessed by Linear regression, adjusted for age. 
inflammatory marker that is related to both MetS and cardiovascular events; and found that adiponectin was inversely correlated with hs-CRP levels, which is in agreement with earlier studies [50] inferring that adiponectin may be an important link between adiposity, inflammation and Type 2 DM [41]. Therefore, adiponectin may directly or indirectly affect CRP levels through modulating inflammatory cascades [35]. Moreover, we found a positive association between serum leptin levels and hs-CRP, which can be explained in part by the fact that adipocytes by serving as a common source for both leptin and inflammatory cytokines contribute to CRP synthesis. Leptin may directly induce production of IL-6, resulting in up-regulation of hepatic CRP production [26].

Serum hs-CRP levels were higher in both obese individuals and non-obese Type 2 DM compared to control group. Unlike that of leptin and LAR, serum hs-CRP levels were higher in non-obese Type $2 \mathrm{DM}$ than that in obese subject, which is concordant with several crosssectional studies showing an increase of CRP levels in patients with diabetes [32,35,51,52]. Epidemiological studies have demonstrated an increase in plasma levels of inflammatory markers such as CRP, IL-6 and TNF- $\alpha$ in patients with MetS and also in those with clinically overt Type 2 DM [8]. C-reactive protein also appears to progressively increase when glucose metabolism deteriorates, as evident in subjects with IFG and Type 2 DM $[34,53]$. The significant increment of serum hs-CRP levels in our non-obese Type $2 \mathrm{DM}$, and the positive correlation between hs-CRP and HOMA-IR suggest that chronic inflammation may play a role in the development of insulin resistance and Type 2DM. The pathophysiological mechanisms linking obesity to elevated levels of CRP are well recognized [4]. In a recent systematic review and meta-analysis, obesity was strongly associated with elevated levels of CRP in all populations observed [54]. The ongoing debate regarding the association among chronic inflammatory states; insulin resistance and obesity provide a conflicting hypothesis that chronic inflammatory state originates from obesity and drives the insulin resistant condition. Moreover, hs-CRP in non-diabetic subjects was associated with decreased HDL-c and IS and increased BMI, waist circumference, SBP, DBP, TG, FBG, insulin, HOMA-IR and HOMA- $\beta$, which is in line with previous studies demonstrating a significant correlation between CRP levels and features of the MetS; including adiposity, hyperinsulinemia and IR $[55,56]$. The observed strong association of fasting insulin with CRP concentration has previously been demonstrated [57].

There were some limitations in this study; first, the study is hospital based and all subjects were male therefore the findings may not generally be applicable to the overall population. Second, the sample size was small, limiting its statistical power for detecting associations. Third, the $\beta$-cell function was evaluated using the homeostasis model (HOMA- $\beta$ and HOMA-IR) as there is no "gold standard" method to evaluate $\beta$-cell function/ mass in vivo. Nevertheless, this study represents a simultaneous investigation of relationships between serum adipokine profile and inflammatory markers in Yemeni non-obese Type 2 DM patients.

In conclusion, plasma adiponectin was not affected by diabetes per se, suggesting that the often reported alterations in plasma adiponectins in Type 2 DM may be due to excess adipose tissue mass/ obesity. Adiponectin and leptin exhibited opposing and variable correlations with obesity, IR and the components of the metabolic syndrome. In addition, LAR was strongly correlated with the HOMA-IR supporting findings that LAR could be a potential marker of IR. The inverse association between adiponectin and hs-CRP infers that adiponectin may be an important link between adiposity, inflammation and Type 2 DM. Moreover, the significant increment of hs-CRP in non-obese Type $2 \mathrm{DM}$, and its positive correlation with HOMA-IR suggest that chronic inflammation may play a role in the development of insulin resistance and Type 2DM.

\section{Competing interests}

The authors have no competing interest to declare.

\section{Authors' contributions}

MA designed the study, participated in the interpretation of data, wrote the manuscript and gave the final approval of the version to be published. ZA collected the samples and carried out the biochemical and Statistical analysis. RS participated in the analysis and interpretation of data. AA assisted in the interpretation of data. All authors read and approved the final manuscript.

Received: 26 June 2014 Accepted: 4 September 2014

Published: 16 September 2014

\section{References}

1. Stumvoll M, Goldstein B, van Haeften T: Type 2 diabetes: principles of pathogenesis and therapy. Lancet 2005, 365:1333-1346.

2. Kahn SE: The relative contributions of insulin resistance and beta-cell dysfunction in the pathophysiology of type 2 diabetes. Diabetologia 2008, 46:3-19.

3. Jensen MD: Role of body fat distribution and the metabolic complications of obesity. J Clin Endocrinol Metab 2008, 93:S57-S63.

4. Bastard JP, Maachi M, Lagathu C, Kim MJ, Caron M, Vidal H, Capeau J, Feve B: Recent advances in the relationship between obesity, inflammation, and insulin resistance. Eur Cytokine Netw 2006, 17:4-12.

5. Rasouli N, Kern PA: Adipocytokines and the metabolic complications of obesity. J Clin Endocrinol Metab 2008, 93:S64-S73.

6. Badawi A, Klip A, Haddad P, Cole D, Garcia Bailo B, El-Sohemy A, Karmali M: Type 2 diabetes mellitus and inflammation: prospects for biomarkers of risk and nutritional intervention. Diab Metab Syndr Obesity: Targets and Therapy 2010, 3:173-186.

7. Donath MY, Shoelson SE: Type 2 diabetes as an inflammatory disease. Nat Rev Immunol 2011, 11:98-107.

8. Mirza S, Hossain M, Mathews C, Martinez P, Pino P, Gay JL, Rentfro A, McCormick JB, Fisher-Hoch SP: Type 2-diabetes is associated with elevated levels of TNF-alpha, IL- 6 and adiponectin and low levels of leptin in a population of Mexican Americans: a cross-sectional study. Cytokine 2012, 57(1):136-142. 
9. Calle MC, Fernandez ML: Inflammation and type 2 diabetes. Diabetes Metab 2012, 38(3):183-191

10. King GL: The role of inflammatory cytokines in diabetes and its complications. J Periodontol 2008, 79:1527-1534.

11. Kadowaki T, Yamauchi T, Kubota N, Hara K, Ueki K, Tobe K: Adiponectin and adiponectin receptors in insulin resistance, diabetes, and the metabolic syndrome. J Clin Invest 2006, 116:1784-1792.

12. Turer AT, Scherer PE: Adiponectin: mechanistic insights and clinical implications. Diabetologia 2012, 55:2319-2326.

13. Skurk T, Alberti-Huber C, Herder C, Hauner H: Relationship between adipocyte size and adipokine expression and secretion. J Clin Endocrinol Metab 2007, 92:1023-1033.

14. Herder C, Schneitler S, Rathmann W, Haastert B, Schneitler H, Winkler H, Bredahl R, Hahnloser E, Martin S: Low-grade inflammation, obesity, and insulin resistance in adolescents. J Clin Endocrinol Metab 2007, 92:4569-4574.

15. Saltevo J, Laakso M, Jokelainen J, Keinanen-Kiukaanniemi S, Kumpusalo E, Vanhala M: Levels of adiponectin, C-reactive protein and interleukin-1 receptor antagonist are associated with insulin sensitivity: a population based study. Diabetes Metab Res Rev 2008, 24:378-383.

16. Ley SH, Harris SB, Connelly PW, Mamakeesick M, Gittelsohn J, Hegele RA, Retnakaran R, Zinman B, Hanley AJG: Adipokines and incident type 2 diabetes in an aboriginal Canadian [corrected] population: the Sandy Lake health and diabetes project. Diabetes Care 2008, 31:1410-1415.

17. Tabak AG, Brunner EJ, Miller MA, Karanam S, Mc Ternan PG, Cappuccio FP, Witte DR: Low serum adiponectin predicts 10-year risk of type 2 diabetes and $\mathrm{HbA} 1 \mathrm{c}$ independently of obesity, lipids, and inflammation: Whitehall II study. Horm Metab Res 2009, 41:626-629.

18. Kishida K, Funahashi T, Shimomura I: Molecular mechanisms of diabetes and atherosclerosis: role of adiponectin. Endocrine Metab Immune Disor - Drug Targets 2012, 12:118-131.

19. Ohashi K, Ouchi N, Matsuzawa Y: Anti-inflammatory and anti-atherogenic properties of adiponectin. Biochimie 2012, 94:2137-2142.

20. Sharma PK, Bhansali A, Sialy R, Malhotra S, Pandhi P: Effects of pioglitazone and metformin on plasma adiponectin in newly detected type 2 diabetes mellitus. Clin Endocrinol 2006, 65:722-728.

21. Miazgowski T, Dziwura-Ogonowska J, Safranow K, Iskierska K, Widecka K: Changes in adiponectin level and fat distribution in patients with type 2 diabetes. Eur J Clin Invest 2014, 44(2):192-199.

22. Lindsay RS, Funahashi T, Hanson RL, Matsuzawa Y, Tanaka S, Tataranni A, Knowler WC, Krakoff J: Adiponectin and development of type 2 diabetes in the Pima Indian population. Lancet 2002, 360:57-58.

23. Mather KJ, Funahashi T, Matsuzawa Y, Edelstein S, Bray GA, Kahn SE, Crandall J, Marcovina S, Goldstein B, Goldberg R: Adiponectin, change in adiponectin, and progression to diabetes in the diabetes prevention program. Diabetes 2008, 57:980-986.

24. Thorand B, Zierer A, Baumert J, Meisinger C, Herder C, Koenig W: Associations between leptin and the leptin/adiponectin ratio and incident type 2 diabetes in middle-aged men and women: results from the MONICA/KORA Augsburg Study 1984-2002. Diabetic Med 2010, 27:1004-1011.

25. Lindberg S, Jensen JS, Bjerre M, Pedersen SH, Frystyk J, Flyvbjerg A, Galatius S, Jeppesen J, Mogelvang R: Adiponectin, type 2 diabetes and cardiovascular risk. Eur J Preventive Cardiol 2013, published online 21 November.

26. Otero M, Lago R, Lago F, Casanueva FF, Dieguez C, Gomez-Reino JJ, Gualillo O: Leptin, from fat to inflammation: Old questions and new insights. FEBS Lett 2005, 579:295-301.

27. Farooqi IS, O'Rahilly S: Leptin: a pivotal regulator of human energy homeostasis. Am J Clin Nutr 2009, 89:980S-984S.

28. Myers MG, Cowley MA, Munzberg H: Mechanisms of leptin action and leptin resistance. Ann Rev Physiol 2008, 70:537-556.

29. Martin SS, Qasim A, Reilly MP: Leptin resistance: a possible interface of inflammation and metabolism in obesity-related cardiovascular disease. J Am Coll Cardiol 2008, 52:1201-1210.

30. Schmidt MI, Duncan BB, Vigo A, Pankow JS, Couper D, Ballantyne CM, Hoogeveen RC, Heiss G: Leptin and incident type 2 diabetes: risk or protection? Diabetologia 2006, 49:2086-2096.

31. Abdelgadir M, Elbagir M, Eltom M, Berne C, Ahrén B: Reduced leptin concentrations in subjects with type 2 diabetes mellitus in Sudan. Metabolism 2002, 51:304-306.
32. Bahceci M, Gokalp D, Bahceci S, Tuzcu A, Atmaca S, Arikan S: The correlation between adiposity and adiponectin, tumor necrosis factor alpha, interleukin- 6 and high-sensitivity c-reactive protein levels. Is adipocyte size associated with inflammation in adults? J Endocrinol Invest 2007, 30:210-214.

33. Lilja M, Rolandsson $\mathrm{O}$, Norberg $M$, Soderberg $\mathrm{S}$ : The impact of leptin and adiponectin on incident type 2 diabetes is modified by sex and insulin resistance. Metab Syndr Relat Disord 2012, 10:143-151.

34. Putz DM, Goldner WS, Bar RS, Haynes WG, Sivitz Wl: Adiponectin and C-reactive protein in obesity, type 2 diabetes, and monodrug therapy. Metabolism 2004, 53(11):1454-1461.

35. Yuan G, Zhou L, Tang J, Yang Y, Gu W, Li F, Hong J, Gu Y, Li X, Ning G, Chen M: Serum CRP levels are equally elevated in newly diagnosed type 2 diabetes and impaired glucose tolerance and related to adiponectin levels and insulin sensitivity. Diabetes Res Clin Pract 2006, 72(3):244-250.

36. Neuparth MJ, Proença JB, Santos-Silva A, Coimbra S: Adipokines, oxidized low- density lipoprotein, and C-reactive protein levels in lean, overweight, and obese Portuguese patients with type 2 diabetes. Obesity 2013, Article ID 142097.

37. Hansen D, Dendale $P$, Beelen M, Jonkers RAM, Mullens A, Corluy L, Meeusen R, van Loon LJC: Plasma adipokine and inflammatory marker concentrations are altered in obese, as opposed to nonobese, type 2 diabetes patients. Eur J Appl Physiol 2010, 109:397-404.

38. Ryo M, Nakamura T, Kihara S, Kumada M, Shibazaki S, Takahashi M, Nagai M, Matsuzawa Y, Funahashi T: Adiponectin as a biomarker of the metabolic syndrome. Circulation J 2004, 68:975-981.

39. Mojiminiyi OA, Abdella NA, Al Arouj M, Ben Nakhi A: Adiponectin, insulin resistance and clinical expression of the metabolic syndrome in patients with type 2 diabetes. Int J Obesity 2007, 31:213-220.

40. Lee JM, Kim SR, Yoo SJ, Hong OK, Son HS, Chang SA: The relationship between adipokines, metabolic parameters and insulin resistance in patients with metabolic syndrome and type 2 diabetes. $J$ Int Med Res 2009, 37:1803-1812.

41. Krakoff J, Funahashi T, Stehouwer CD, Schalkwijk CG, Tanaka S, Matsuzawa Y, Kobes S, Tataranni PA, Hanson RL, Knowler WC, Lindsay RS: Inflammatory markers, adiponectin, and risk of type 2 diabetes in the pima Indian. Diabetes Care 2003, 26:1745-1751.

42. Fasshauer M, Klein J, Neumann S, Eszlinger M, Paschke R: Hormonal regulation of adiponectin gene expression in 3 T3-L1 adipocytes. Biochem Biophys Res Commun 2002, 290:1084-1089.

43. Mohlig M, Wegewitz U, Osterhoff M, Isken F, Ristow M, Pfeiffer AF, Spranger J: Insulin decreases human adiponectin plasma levels. Horm Metab Res 2002, 34:655-658.

44. Fasshauer M, Kralisch S, Klier M, Lossner U, Bluher M, Klein J, Paschke R: Adiponectin gene expression and secretion is inhibited by interleukin-6 in 3 T3-L1 adipocytes. Biochem Biophys Res Commun 2003, 301:1045-1050.

45. Hotta K, Funahashi T, Arita Y, Takahashi M, Matsuda M, Okamoto M, Iwahashi H, Kuriyama H, Ouchi N, Maeda K, Nishida M, Kihara S, Sakai N, Nakajima T, Hasegawa K, Muraguchi M, Ohmoto Y, Nakamura T, Ya-mashita S, Hanafusa T, Matsuzawa Y: Plasma concentrations of a novel, adipose- specific protein, adiponectin, in type 2 diabetic patients. Arterio Thromb Vascul Biol 2000, 20:1595-1599.

46. Considine RV, Sinha MK, Heiman ML, Kriauciunas A, Stephens TW, Nyce MR, Ohannesian JP, Marco CC, McKee LJ, Bauer TL, Caro JF: Serum immunoreactive- leptin concentration in normal weight and obese humans. N Engl J Med 1996, 334:292-295.

47. Park K-G, Park KS, Kim M-J, Kim H-S, Suh Y-S, Ahn JD, Park K-K, Chang Y-C, Lee I-K: Relationship between serum adiponectin and leptin concentrations and body fat distribution. Diabetes Res Clin Pract 2004, 63(2):135-142.

48. Tajtakova M, Petrasova D, Pidanicova A, Gallovicova A, Blanarova C, Petrovicova J: Serum levels of leptin, adiponectin, retinol binding protein 4 and leptin/adiponectin molar ratio as another possible marker of insulin resistance in obese. Bratis/ Lek Listy 2010, 111:212-215.

49. Satoh N, Naruse M, Usui T, Tagami T, Suganami T, Yamada K, Kuzuya H, Shimatsu A, Ogawa Y: Leptin to adiponectin ratio as a potential atherogenic index in obese type 2 diabetic patients. Diabetes Care 2004, 27:2488-2490

50. Schulze MB, Rimm EB, Shai I, Rifai N, Hu FB: Relationship between adiponectin and glycemic control, blood lipids, and inflammatory markers in men with type 2 diabetes. Diabetes Care 2004, 27:1680-1687. 
51. Marques-Vidal P, Bastardot F, von Kanel R, Paccaud F, Preisig M, Waeber G, Vollenweider P: Association between circulating cytokine levels, diabetes and insulin resistance in a population-based sample (CoLaus study). Clin Endocrinol 2013, 78:232-241.

52. Wang X, Bao W, Liu J, Ouyang YY, Wang D, Rong S, Xiao X, Shan ZL, Zhang Y, Yao P, Liu LG: Inflammatory markers and risk of type 2 diabetes: a systematic review and meta-analysis. Diabetes Care 2013, 36(1):166-175.

53. Aronson D, Bartha P, Zinder O, Kerner A, Shitman E, Markiewicz W, Brook GJ, Levy Y: Association between fasting glucose and C-reactive protein in middle-aged subjects. Diabetic Med 2004, 21(1):39-44.

54. Choi J, Joseph L, Pilote L: Obesity and C-reactive protein in various populations: a systematic review and meta-analysis. Obesity Rev 2013, 14:232-244

55. Temelkova-Kurktschiev T, Siegert G, Bergmann S, Henkel E, Koehler C, Jaross W, Hanefeld M: Subclinical inflammation is strongly related to insulin resistance but not to impaired insulin secretion in a high risk population for diabetes. Metabolism 2002, 51:743-749.

56. Chou HH, Hsu LA, Liu CJ, Teng MS, Wu S, Ko YL: Insulin resistance is associated with C-reactive protein independent of abdominal obesity in nondiabetic Taiwanese. Metabolism 2010, 59(6):824-830.

57. Pradhan AD, Cook NR, Buring JE, Manson JE, Ridker PM: C-reactive protein is independently associated with fasting insulin in nondiabetic women. Arterioscler Thromb Vasc Biol 2003, 23:650-655.

doi:10.1186/1758-5996-6-99

Cite this article as: Al-Hamodi et al:: Association of adipokines, leptin/ adiponectin ratio and C-reactive protein with obesity and type 2 diabetes mellitus. Diabetology \& Metabolic Syndrome 2014 6:99.

\section{Submit your next manuscript to BioMed Central and take full advantage of:}

- Convenient online submission

- Thorough peer review

- No space constraints or color figure charges

- Immediate publication on acceptance

- Inclusion in PubMed, CAS, Scopus and Google Scholar

- Research which is freely available for redistribution 